\title{
Thyme and Savory Essential Oil Vapor Treatments Control Brown Rot and Improve the Storage Quality of Peaches and Nectarines, but Could Favor Gray Mold
}

\author{
Karin Santoro ${ }^{1,2,+}$, Marco Maghenzani ${ }^{1,+}$, Valentina Chiabrando ${ }^{1}$, Pietro Bosio ${ }^{2}$ (D), \\ Maria Lodovica Gullino ${ }^{1,2}$, Davide Spadaro ${ }^{1,2, *}$ (i) and Giovanna Giacalone ${ }^{1}$ \\ 1 Department of Agricultural, Forestry and Food Sciences (DISAFA), University of Turin, \\ Largo Paolo Braccini 2 (ex-Via L. da Vinci 44), 10095 Grugliasco, Italy; karin.santoro@unito.it (K.S.); \\ marco.maghenzani@unito.it (M.M.); valentina.chiabrando@unito.it (V.C.); \\ marialodovica.gullino@unito.it (M.L.G.); giovanna.giacalone@unito.it (G.G.) \\ 2 AGROINNOVA-Centre of Competence for the Innovation in the Agro-environmental Sector, \\ University of Turin, Largo Paolo Braccini 2 (ex-Via L. da Vinci 44), 10095 Grugliasco, Italy; \\ pietro.bosio@unito.it \\ * Correspondence: davide.spadaro@unito.it; Tel.: +39-011-6708-942 \\ + These two authors contributed equally to this work.
}

Received: 6 November 2017; Accepted: 28 December 2017; Published: 5 January 2018

\begin{abstract}
The effect of biofumigation, through slow-release diffusors, of thyme and savory essential oils (EO), was evaluated on the control of postharvest diseases and quality of peaches and nectarines. EO fumigation was effective in controlling postharvest rots. Naturally contaminated peaches and nectarines were exposed to EO vapors for 28 days at $0{ }^{\circ} \mathrm{C}$ in sealed storage cabinets and then exposed at $20^{\circ} \mathrm{C}$ for five days during shelf-life in normal atmosphere, simulating retail conditions. Under low disease pressure, most treatments significantly reduced fruit rot incidence during shelf-life, while, under high disease pressure, only vapors of thyme essential oil at the highest concentration tested $(10 \% v / v$ in the diffusor) significantly reduced the rots. The application of thyme or savory EO favored a reduction of brown rot incidence, caused by Monilinia fructicola, but increased gray mold, caused by Botrytis cinerea. In vitro tests confirmed that $M$. fructicola was more sensitive to EO vapors than B. cinerea. Essential oil volatile components were characterized in storage cabinets during postharvest. The antifungal components of the essential oils increased during storage, but they were a low fraction of the volatile organic compounds in storage chambers. EO vapors did not influence the overall quality of the fruit, but showed a positive effect in reducing weight loss and in maintaining ascorbic acid and carotenoid content. The application of thyme and savory essential oil vapors represents a promising tool for reducing postharvest losses and preserving the quality of peaches and nectarines.
\end{abstract}

Keywords: biofumigation; Monilinia spp.; Botrytis spp.; essential oils; stone fruit; postharvest disease

\section{Introduction}

Peaches and nectarines (Prunus persica (L.) Batsch) are fruit rich in vitamins, fibers and other phytochemical compounds, such as carotenes and polyphenols, which are important for a healthy diet [1,2]. Stone fruit are consumed worldwide and represent one of the most important fruit. In recent years, peach and nectarine production increased progressively [3] and the main global producer is China with over 12 million tons, followed by Spain and Italy, which produce 3 million tons annually [4]. Peaches and nectarines are the 3rd most important fruit crop in the European Union after apples and pears [5]. 
During storage, the quality characteristics and some commercial parameters of these fruit can decrease, at a rate depending on the storage conditions, due to postharvest diseases and senescence processes [6].

The most common postharvest pathogens on stone fruit are Monilinia spp. (M. fructigena Honey, M. fructicola (G. Winter) Honey, and M. laxa (Aderh. and Ruhland) Honey), agents of brown rot, Botrytis cinerea Pers. agent of gray mold, Penicillium expansum Link, agent of blue mold, Alternaria spp., agent of black mold, and Rhizopus stolonifer, Ehrenb., agent of Rhizopus rot $[7,8]$. On peaches, postharvest losses can cause even higher damage than preharvest diseases [9]. Crop protection in Europe should be performed in the orchard because only one fungicide (fludioxonil) can be used on stone fruit after harvesting, but the supermarket chains typically request either no further postharvest treatments or a limited number of active ingredients, as residues, on the fruit. The last fungicide has to be applied 1 or 2 weeks before harvesting, to guarantee a high level of fruit protection against pathogens during storage, and to remain below the maximum residue limits imposed by European legislation [10]. Moreover, consumer attention is attracted by environmentally friendly production practices, preferring foods treated with natural products instead of conventional pesticides [11]. At present, Monilinia spp. control depends on an integrated strategy based on orchard fungicide spray programs and maintenance of proper storage conditions in the packinghouse and during distribution [12].

Hence, intense research efforts focus on developing innovative, unconventional, sustainable strategies to preserve fruit quality and decrease food losses. The most promising control approaches are the use of microorganisms and natural products with intrinsic antimicrobial properties [13,14]. Essential oils (EOs) represent a powerful tool to reduce the environmental impact of fruit production [15]. The efficacy of plant EOs has been extensively evaluated in vitro [16], but a few studies have been performed in vivo [17]. However, these treatments may modify the organoleptic characteristics of fruit, changing taste or flavor during cold storage.

The antifungal activity of EOs is determined by their chemical composition. In particular, aldehydes, phenols and ketones considerably inhibit pathogen growth. Thymol, carvacrol and $p$-anisaldehyde have a proven fungicidal activity and EOs rich in these components showed the highest inhibitory activity against many postharvest pathogens, such as Penicillium digitatum [18], Colletotrichum gloeosporioides [19] and R. stolonifer [20]. EOs of thyme (Thymus vulgaris) and savory (Satureja montana) are mainly composed of thymol and carvacrol [21], which are highly effective in controlling fungal pathogens. Generally, the efficacy of EOs is investigated through direct contact with fruit, by application through spraying or dipping [22]. However, these application methods can have undesired effects, including phytotoxicity and organoleptic modification of treated fruit. Only a few studies have reported the efficacy of EO treatments through biofumigation, focusing on phytopathological aspects [23]. Scientific research recently started to pay particular attention to the assessment of the antifungal activity of EO vapors $[24,25]$. Fumigation with thyme and savory EOs resulted in effective control of several postharvest pathogens, showing antifungal activity against Colletotrichum [26], Aspergillus, Penicillium, Mucor and Trichoderma spp. [27] The use of EOs through fumigation avoids the direct contact with the product, reducing the possibility of influencing the sensorial profile.

The aim of this study was to investigate the effect of the vapor phase of thyme and savory EOs, applied by fumigation through slow-release diffusors, on both quality parameters and postharvest diseases of peaches and nectarines, during cold storage and shelf life. Savory and thyme solid diffusors were prepared at two different concentrations and they were used to treat naturally infected peaches and nectarines. In order to clarify how essential oils diffuse and persist in cold rooms, the atmospheric composition of the storage cabinets was analyzed during cold storage. At the same time, the antimicrobial activity of essential oil vapors was evaluated in vitro on conidial germination of $M$. fructicola and B. cinerea, two of the main postharvest pathogens of peaches and nectarines.

\section{Materials and Methods}

The EOs of thyme (Thymus vulgaris) and savory (Satureja montana) used in the assays were prepared by Soave (Turin, Italy). The compositional analyses were performed using a gas chromatograph 
Shimadzu GC-2010 Plus (Shimadzu, Kyoto, Japan) equipped with a mass spectrometer GCMS-QP 2010 Ultra (Shimadzu) and a split-splitless injector. The gas chromatograph was fitted with a $30 \mathrm{~m} \times 0.25 \mathrm{~mm}$ fused silica capillary Zebron ZB-5MSi column (Phenomenex, Torrance, CA, USA) with $0.25 \mu \mathrm{m}$ film thickness. Helium carrier gas using a linear velocity of $37 \mathrm{~cm} / \mathrm{s}$ with a constant flow rate of $1.0 \mathrm{~mL} / \mathrm{min}$ was used. The pressure was $55 \mathrm{kPa}$ and total flow was $105 \mathrm{~mL} / \mathrm{min}$. Ion electron impact spectra at $70 \mathrm{eV}$ were recorded in scan mode $(30-700 \mathrm{~m} / \mathrm{z})$.

For savory essential oil, the oven program started with an initial temperature of $50{ }^{\circ} \mathrm{C}$ for $3 \mathrm{~min}$, heating at $5{ }^{\circ} \mathrm{C} / \mathrm{min}$ to $70{ }^{\circ} \mathrm{C}, 70{ }^{\circ} \mathrm{C}$ for $5 \mathrm{~min}$, heating at $1{ }^{\circ} \mathrm{C} / \mathrm{min}$ to $90^{\circ} \mathrm{C}$, heating at $5{ }^{\circ} \mathrm{C} / \mathrm{min}$ to $150{ }^{\circ} \mathrm{C}$, and finally heating at $40^{\circ} \mathrm{C} / \mathrm{min}$ to $270{ }^{\circ} \mathrm{C}$, held for $5 \mathrm{~min}$. For thyme essential oil, the same protocol was used without the isothermal phase at $70{ }^{\circ} \mathrm{C}$ for $5 \mathrm{~min}$. For both essential oils, the injection temperature was set at $250{ }^{\circ} \mathrm{C}$ and the ion source and the interface were both set at $280{ }^{\circ} \mathrm{C}$.

Pure essential oil of savory and thyme were diluted at $1 \%$ and $10 \%$ in $n$-hexane (VWR, Radnor, PA, USA) for direct injection using split mode $(80 \%)$. Sampling in the chambers was performed using SPME fiber assembly $100 \mu \mathrm{m}$ PDMS (Supelco Analytical, Bellefonte, PA, USA) for $5 \mathrm{~min}$ in triplicate at 1,14 and 28 days of incubation whereby the injector was in splitless mode. Relative composition (percentage) of volatile compounds was calculated by comparing peak area to area of total chromatogram (from 7.5 to $40 \mathrm{~min}$ ). Absolute quantification was calculated for carvacrol and thymolusing a standard calibration curve between 1 and $50 \mathrm{ppm}(\mathrm{mg} / \mathrm{L})$. Relative quantification was determined for the other compounds, by using standard calibration curve of thymol for thyme essential oil and standard calibration curve of carvacrol for savory essential oil.

Peaches ('Vista Rich') and nectarines ('Sweet Red') were harvested from two different orchards located in Lagnasco (Cuneo, Italy, $44^{\circ} 37^{\prime} 33^{\prime \prime} 60 \mathrm{~N}, 07^{\circ} 33^{\prime} 21^{\prime \prime} 24 \mathrm{E}$ ) at the firm-ripe stage and transported immediately to the laboratory of DISAFA, University of Torino, during the summer of 2015. All fruit were sorted by size. Defect-free fruit were randomly divided into five lots of 350 fruit each. Each lot was treated in a different way and further divided into 5 replicates of 70 fruit. Each replicate was a box kept in a container at the same temperature, but different atmosphere according to the treatment.

EO diffusors were made by adding EO $(10 \% v / v)$, sterilized deionized water $(88 \% v / v)$ and Tween $20(2 \% v / v)$ (Merck, Darmstadt, Germany) to agar-agar (Merck) (15 g/L). Lower EO concentrations were obtained by serial dilutions. $50 \mathrm{~mL}$ of medium were poured into Petri dishes and after agar solidification, 5 diffusors were installed in storage cabinets under the fruit boxes. Fruit were stored in refrigerator cabinets $(75 \times 70 \times 65 \mathrm{~cm})$ at $0{ }^{\circ} \mathrm{C}$ and $98 \%$ relative humidity for 28 days. Fumigation was performed at $1 \%$ and $10 \% \mathrm{EO}$ concentrations. A total of four treatments were tested: thyme $\mathrm{EO}$ at $1 \%$, thyme EO at $10 \%$, savory EO at $1 \%$ and savory EO at $10 \%$. An untreated control was included. The analyses were performed at 1, 14 and 28 days of cold storage.

After harvesting, healthy sound fruit were selected. Rotten fruit were counted and incidence of diseased fruit was calculated for each treatment every 7 days up to 28 days of storage, and for 5 days of shelf life at $20^{\circ} \mathrm{C}$. Pathogens were isolated by transferring small pieces of symptomatic fruit tissues, previously washed in $1 \%$ sodium hypochlorite and rinsed in sterile deionized water, onto potato dextrose agar (PDA, Merck) plates amended with $25 \mathrm{mg} / \mathrm{L}$ streptomycin sulfate (Merck). A 7-day-old culture was used for DNA extraction by using the EZNA Plant DNA Kit (Omega Bio-Tek, Norcross, GA, USA). The internal transcribed spacer (ITS) region of rDNA of 50 isolates was amplified using the ITS1/ITS4 primers [28]. The PCR reaction mixture comprised $2 \mu \mathrm{L} 10 \times$ PCR buffer, $1 \mu \mathrm{L}$ ITS1 primer at $10 \mathrm{mM}, 1 \mu \mathrm{L}$ of ITS4 primer at $10 \mathrm{mM}, 1 \mu \mathrm{L}$ of nucleotides mixture at $5 \mathrm{mM}, 12 \mu \mathrm{L}$ of MilliQ autoclaved water, $0.8 \mu \mathrm{L}$ of $\mathrm{MgCl}_{2}$ at $25 \mathrm{mM}, 0.2 \mu \mathrm{L}$ of Taq polymerase and $2 \mu \mathrm{L}$ of template DNA. PCR cycles included a denaturing step at $95^{\circ} \mathrm{C}$ for 2 min and 35 cycles as follows: $94{ }^{\circ} \mathrm{C}$ for $30 \mathrm{~s}, 55^{\circ} \mathrm{C}$ for $30 \mathrm{~s}, 72{ }^{\circ} \mathrm{C}$ for $1 \mathrm{~min}$ and a final elongation step at $72{ }^{\circ} \mathrm{C}$ for $7 \mathrm{~min}$. ITS amplicons were sequenced by BMR Genomics (Padua, Italy), and DNA sequences were compared with those present in the NCBI database and deposited with accession numbers.

The effect of essential oils on conidial germination was investigated on two main peach and nectarine pathogens, B. cinerea and M. fructicola. Two virulent strains isolated from peaches were 
stored on agar slant at $4{ }^{\circ} \mathrm{C}$ until use. B. cinerea conidial suspension was obtained from 15 days of culture grown on PDA+ streptomycin $25 \mathrm{mg} / \mathrm{L}$ at $25^{\circ} \mathrm{C}$. M. fructicola was cultured on tomato agar plate ( $250 \mathrm{~mL}$ of tomato puree, $750 \mathrm{~mL}$ of deionized water and $20 \mathrm{~g}$ of agar) amended with $25 \mathrm{mg}$ of streptomycin for 5 days. $5 \mathrm{~mL}$ of sterile deionized water were added to the plate and the mycelium was gently scraped with L-shaped spreader to detach the conidia. Conidial suspension was filtered through four layers of sterile cheesecloth and $100 \mu \mathrm{L}$ were spread on PDA+ streptomycin plates. PDA plates were sealed with the essential oil diffusor. EOs were added to the diffusors at $350 \mu \mathrm{L} / \mathrm{L}$ and $35 \mu \mathrm{L} / \mathrm{L}$, a concentration proportional to the quantity present in the cabinet considering the concentration of EO diffusor, the number of diffusors per cabinet and the volume of the cabinet and the plates. Conidial germination was assessed after $20 \mathrm{~h}$ for $B$. cinerea and $36 \mathrm{~h}$ for $M$. fructicola counting 100 conidia per plate. Three replicates were used for each treatment and the assay was repeated twice. Conidia were considered germinated when the germ tube exceeded the conidial length.

Weight loss was determined by weighing 30 fruit per treatment at the beginning of the trial (zero time) and during storage (7, 14, 21 and 28 days of storage, and at 5 days for shelf life). Values are reported as shown in Equation (1).

$$
\% \text { weight loss }=\frac{\text { initial weight }- \text { final weight }}{\text { initial weight }} \times 100
$$

The color parameters were measured weekly during cold storage, with a Minolta chromameter (CR400, Konica Minolta Sensing, Inc., Osaka, Japan), calibrated with a standard white plate, using the CIE $L^{*} C^{*} h$ (lightness, chroma/saturation and hue angle) scale. The surface of 30 fruit (ground and over color) was evaluated per treatment.

The carotenoid content was determined every 14 days, using the method reported by Talcott and Howard [29]. The carotenoids were extracted using $10 \mathrm{~mL}$ of extraction solvent (ethanol/acetone $w / w$ with $0.2 \%$ butylhydroxytoluene) and $2 \mathrm{~g}$ of fresh sample from $10 \mathrm{fruit}$, homogenized at 24,000 rpm for 1 min using an Ultra-Turrax T-25 Tissue homogenizer (IKA ${ }^{\circledR}$-Labortechnik, Saufen, Germany). The samples were then centrifuged at $2900 \mathrm{rpm}$ for $20 \mathrm{~min}$ at $2{ }^{\circ} \mathrm{C}$ (Avanti J-25 centrifuge, Beckman Instruments, Palo Alto, CA, USA). The recovered supernatants were combined with $30 \mathrm{~mL}$ of extraction solvent, $25 \mathrm{~mL}$ of hexane and $12.5 \mathrm{~mL}$ of nanopure water. The tubes were left in the dark at $4{ }^{\circ} \mathrm{C}$ for $1 \mathrm{~h}$, then the samples were transferred to quartz cuvettes. Absorbance was measured using a UV-visible spectrophotometer (DU 530, Beckman Coulter, Brea, CA, USA) at $450 \mathrm{~nm}$, with $\beta$-carotene as an external standard. The results are expressed as $\mu \mathrm{g} \beta$-carotene equivalents per $\mathrm{kg}$ weight of fruit and are an average of three replicates per treatment and per time point (at 0,14 and 28 days of storage).

Ascorbic acid (AA) was determined according to Sánchez-Moreno et al. [30] and González-Molina et al. [31], and evaluated at 0, 14 and 28 days (three replicates per treatment and per time point). The ascorbic acid was extracted using $10 \mathrm{~mL}$ of extraction solvent (methanol:water 5:95 $\mathrm{v} / \mathrm{v}$ ) and $10 \mathrm{~g}$ of fruit flesh from 10 fruit per treatment by homogenization with a T-25 Ultra-Turrax for $3 \mathrm{~min}$. Then, $\mathrm{pH}$ was adjusted to 2.2-2.4, and the extract was adsorbed onto a C18 Sep-Pak cartridge (Waters Associates, Milford, MA, USA). The resultant solution was added to 1,2-phenylenediamine dihydrochloride (Fluka Chemika, Neu-Ulm, Switzerland) and left to stand for 37 min before HPLC analysis. The AA and dehydroascorbic acid contents were expressed as $\mathrm{mg} / \mathrm{kg}$ fresh weight. Three replicate analyses were performed on the flesh. The chromatographic system (Agilent Technologies, Inc., Santa Clara, CA, USA) was equipped a Kinetex-C18 column $(4.6 \times 150 \mathrm{~mm}, 5 \mu \mathrm{m}$, Phenomenex, Torrance, CA, USA), a pump and a diode array detector. The system was controlled through HPLC online software (Agilent Technologies, Inc.) at $40{ }^{\circ} \mathrm{C}$. The mobile phase (isocratic) comprised $50 \mathrm{mM}$ monobasic potassium phosphate and $5 \mathrm{mM}$ cetrimide (Sigma-Aldrich Corporation, Saint Louis, MO, USA) in methanol:water $(5: 95 \mathrm{v} / \mathrm{v})$. The flow rate was $0.9 \mathrm{~mL} / \mathrm{min}$. The detector was set at $261 \mathrm{~nm}$ for AA and 348 for dehydroascorbic acid (DHAA). External calibration curves for AA and DHAA, respectively, were used for quantification. The total run time was $15 \mathrm{~min}$. The detection limit is $0.5 \mathrm{mg} / \mathrm{kg}$ of fresh weight. 
Analysis of variance (ANOVA) was performed on the data using Statistica v. 6.0 (Statsoft Inc., Tulsa, OK, USA). Least significant differences (LSD) at a significance level of 0.05 were used to compare treatment means with Tukey's test. Mean values for each time point were considered significantly different at $p \leq 0.05$.

\section{Results and Discussion}

The vapor phase activity makes EOs potential biofumigants of fruit in storage chambers. Slow release diffusors, based on EO gel emulsions, were used to release EO vapor phase during the storage of peaches and nectarines. Pathogens were not inoculated, so only natural pathogen inoculum could develop both on nectarines and peaches.

EO fumigation was effective in controlling postharvest rots of peaches and nectarines, but the efficacy was different in the two experimental conditions. During cold storage, no rots developed either on nectarines 'Sweet Red' or on 'Vista Rich' peaches. Rot incidence on nectarines 'Sweet Red' and peaches 'Vista Rich' greatly differed during shelf life ( 5 days at $\left.20^{\circ} \mathrm{C}\right)$. After shelf life, on nectarines the rot incidence in untreated fruit was $23.3 \%$, while most peaches $(99.3 \%)$ were rotten in untreated control (Figure 1).

a) Rot incidence on nectarines 'Sweet Red'

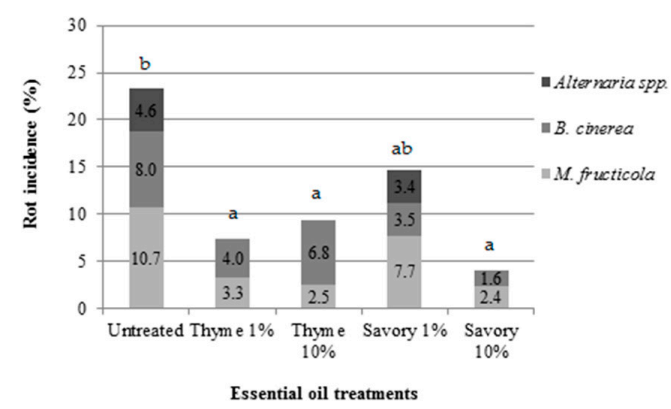

b) Rot incidence on peaches 'Vista Rich'

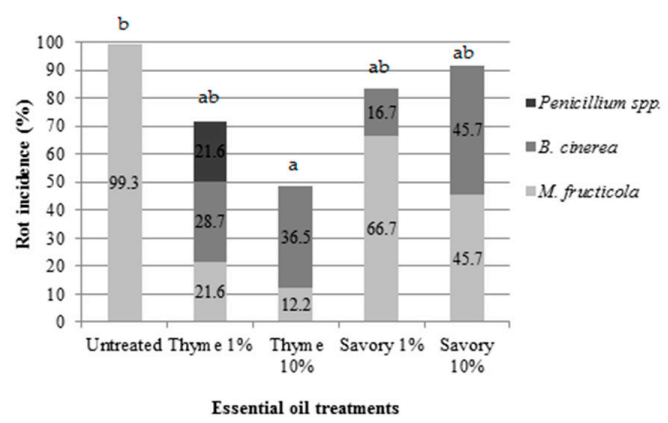

Figure 1. Rot incidence in nectarines 'Sweet Red' (a) and peaches 'Vista Rich' (b) treated with essential oil biofumigation and pathogen incidence (\%) at the end of shelf life ( 5 days at $20{ }^{\circ} \mathrm{C}$ after 28 days of cold storage). Values of the same storage trial, followed by the same letter, are not statistically different by Tukey's Test $(p<0.05)$.

Disease incidence was influenced by the weather conditions during fruit growing. A high incidence of brown rot on peaches, which were harvested one month before nectarines, was favored by fresh and humid weather conditions, while nectarines were harvested in August, after a period characterized by high temperatures and scarce precipitations, which limited the development of brown rot [32].

Untreated control showed the highest percentage of rotten fruit in both trials. The pathogens isolated from rotten fruit were identified using morphological and molecular tools. On nectarines, the postharvest pathogens isolated from untreated fruit were Monilinia fructicola, Botrytis cinerea, and Alternaria spp. (Table 1), with an incidence of $10.7 \%, 8.0 \%$ and $4.6 \%$, respectively.

Table 1. GenBank accession numbers of ITS sequences of some pathogenic isolates from nectarines 'Sweet Red'.

\begin{tabular}{cc}
\hline Isolated Strains & GenBank Accession Number \\
\hline CaF1-Botrytis cinerea & KX304007 \\
S1cF3-Botrytis cinerea & KX304008 \\
CcF5-Monilinia fructicola & KX304009 \\
S1aF1-Monilinia fructicola & KX304010 \\
Cb22-Alternaria sp. & KX304011 \\
Cc12-Alternaria sp. & KX304012 \\
\hline
\end{tabular}


The efficacy of the EO treatments was influenced by the disease incidence: under low disease pressure, three out of four treatments significantly reduced the fruit rot incidence, while under high disease pressure, only vapors of thyme at 10\% significantly reduced the rots compared to the control.

On nectarines, savory EO at $10 \%$ was the most effective treatment, with only $4.0 \%$ of the fruit damaged by postharvest pathogens. All the treatments were effective in controlling postharvest diseases, except for savory EO at 1\%, which was not statistically different from the control at the end of the shelf life (Figure 1a). Thyme EO was very effective in controlling $M$. fructicola. The increase in EO concentration resulted in a decrease of brown rot. B. cinerea was isolated with an incidence of $4.0 \%$ and $6.8 \%$ for $1 \%$ and $10 \%$ thyme EO treatment, respectively.

On nectarines, $M$. fructicola was the major pathogen in untreated fruit ( $47.2 \%$ of rotten fruit), while the relative incidence decreased to $45.0 \%$ and $26.8 \%$ in fruit treated with thyme EO at $1 \%$ and $10 \%$, respectively. B. cinerea affected $34.3 \%, 55.0 \%$ and $73.2 \%$ of rotten fruit in the control, in thyme at $1 \%$ and at 10\%, respectively. After the first report of M. fructicola in Italy in 2009 [33], the pathogen has mainly substituted the endemic species M. laxa in Italian orchards.

Moreover, Alternaria spp. was not isolated in fruit fumigated with thyme EO. Savory EO vapors were less effective in controlling this pathogen because only $10 \%$ concentration inhibited Alternaria spp. growth, while $3.4 \%$ of fruit fumigated with $1 \%$ savory EO showed Alternaria rot. Reduced activity against Alternaria spp. was reported for savory essential oil, moreover the essential oil at $400 \mathrm{ppm}$ favored Alternaria rot [34]. Alternaria spp. is a secondary pathogen of nectarines and the presence on the samples is mainly due to long storage.

On peaches, under high disease pressure, untreated fruit were completely damaged by brown rot. On fruit fumigated with EOs, M. fructicola, B. cinerea and Penicillium spp. were isolated (Figure 1b). The efficacy of thyme EO against $M$. fructicola depended on its concentration. M. fructicola affected only $30 \%$ and $25 \%$ of the rotten fruit fumigated with $1 \%$ and $10 \%$ thyme EO, respectively.

B. cinerea, the causal agent of gray mold, is uncommon on peaches, but its presence can be higher when the incidence of brown rot is low [35]. The application of thyme or savory EO, both on nectarines and on peaches favored a reduction of brown rot incidence, but a concomitant increase of gray mold.

In accordance with the literature, M. fructicola was very sensitive to thyme essential oil [36]. The fungicidal properties of thyme EO are mainly due to thymol, recognized as the most active phenolic compound against postharvest molds [37].

The chemical composition of the EO used in the trial was determined by direct injection. Principal volatile compounds present in pure thyme essential oil were thymol (26.0\%), followed by $p$-cymene, $\alpha$-terpineol and linalool (Table 2 ).

As diffusors, based on EO gel emulsions, were used to release EO vapor phase during the fruit storage, we wanted to determine the concentration of EO compounds in the atmosphere of the chambers during fruit cold storage. The analyses performed in chambers with thyme EO diffusors at $1 \%$ and $10 \%$ showed a very high amount of $p$-cymene, the main volatile organic compound at 1,14 and 28 days. Thymol, instead, was on average $2.0 \%$ during the three samplings in thyme EO at $10 \%$, while in thyme EO at $1 \%$ thymol was $0.40 \%, 3.66 \%$ and $3.67 \%$ at day 1,14 and 28 , respectively. Thymol in storage chambers was released slowly and at lower concentration, compared to the pure essential oil composition. This experiment demonstrated that thymol was slowly released by diffusors during the 28 days of fruit storage in cold chambers, and persisted by increasing in absolute concentration during storage.

Regarding savory essential oil, direct injection showed that the principal volatile compound was linalool (22.2\%), followed by carvacrol (13.3\%), thymol (10.7\%) and eucalyptol (Table 3). 
Table 2. Thyme essential oil composition and volatilized compounds in storage cabinet at 1,14 and 28 days.

\begin{tabular}{|c|c|c|c|c|c|c|c|c|c|c|c|c|c|}
\hline \multirow{3}{*}{ EO * Components } & \multirow{3}{*}{ DI ** $(\%)$} & \multicolumn{6}{|c|}{ Thyme 10\% } & \multicolumn{6}{|c|}{ Thyme 1\% } \\
\hline & & \multicolumn{2}{|c|}{$\mathrm{T} 1$} & \multicolumn{2}{|c|}{ T14 } & \multicolumn{2}{|c|}{ T28 } & \multicolumn{2}{|c|}{ T1 } & \multicolumn{2}{|c|}{ T14 } & \multicolumn{2}{|c|}{ T28 } \\
\hline & & ppm & $(\%)$ & ppm & $(\%)$ & ppm & $(\%)$ & ppm & $(\%)$ & ppm & $(\%)$ & ppm & $(\%)$ \\
\hline$\alpha$-Pinene & 3.59 & 17.35 & 2.59 & 35.32 & 4.19 & 48.44 & 4.64 & 3.76 & 4.07 & 8.31 & 2.10 & 12.74 & 2.60 \\
\hline Camphene & 0.98 & 7.27 & 1.05 & 15.76 & 1.84 & 21.53 & 2.04 & 1.25 & 1.06 & 2.40 & 0.54 & 4.71 & 0.91 \\
\hline$\beta$-Pinene & 0.30 & 3.29 & 0.45 & 6.53 & 0.74 & 8.58 & 0.79 & 0.36 & 0.00 & 1.49 & 0.30 & 2.24 & 0.39 \\
\hline Myrcene & 0.89 & 12.17 & 1.80 & 18.66 & 2.19 & 29.39 & 2.80 & 2.18 & 2.18 & 4.25 & 1.03 & 7.05 & 1.40 \\
\hline$p$-Cimene & 23.52 & 321.89 & 49.07 & 372.43 & 44.56 & 397.13 & 38.30 & 53.21 & 63.38 & 78.13 & 20.59 & 99.92 & 20.89 \\
\hline Linalool & 8.00 & 96.47 & 14.67 & 135.54 & 16.19 & 166.85 & 16.07 & 3.17 & 3.36 & 94.47 & 24.91 & 100.66 & 21.04 \\
\hline Fenchol & 0.45 & 5.55 & 0.79 & 9.23 & 1.06 & 13.69 & 1.29 & 0.36 & 0.00 & 5.39 & 1.33 & 6.00 & 1.18 \\
\hline Terpinen-1-ol & 2.30 & 14.71 & 2.19 & 22.45 & 2.65 & 31.92 & 3.05 & 0.87 & 0.61 & 19.67 & 5.11 & 24.85 & 5.14 \\
\hline Camphor & 0.37 & 3.01 & 0.40 & 4.07 & 0.44 & 6.96 & 0.64 & 1.88 & 1.82 & 3.31 & 0.78 & 4.07 & 0.78 \\
\hline$\beta$-Terpineol & 1.03 & 6.58 & 0.95 & 11.02 & 1.28 & 15.79 & 1.49 & 0.60 & 0.28 & 9.20 & 2.34 & 11.39 & 2.31 \\
\hline Isoborneol & 0.71 & 9.05 & 1.33 & 13.79 & 1.61 & 19.85 & 1.88 & 0.36 & 0.00 & 9.77 & 2.49 & 11.43 & 2.32 \\
\hline Borneol & 1.90 & 12.65 & 1.88 & 22.71 & 2.68 & 29.65 & 2.83 & 0.36 & 0.00 & 29.14 & 7.62 & 22.55 & 4.65 \\
\hline Terpinen-4-ol & 0.67 & 5.36 & 0.76 & 7.32 & 0.83 & 10.79 & 1.01 & 0.36 & 0.00 & 6.00 & 1.49 & 7.01 & 1.39 \\
\hline$\alpha$-Terpineol & 13.40 & 30.12 & 4.54 & 53.57 & 6.37 & 74.71 & 7.18 & 1.51 & 1.37 & 50.54 & 13.28 & 64.49 & 13.45 \\
\hline$\gamma$-Terpineol & 2.60 & 6.73 & 0.97 & 10.74 & 1.24 & 14.32 & 1.35 & 0.36 & 0.00 & 11.19 & 2.86 & 13.30 & 2.71 \\
\hline Thymol & 26.02 & 4.28 & 0.60 & 23.56 & 2.78 & 28.07 & 2.67 & 0.69 & 0.40 & 14.17 & 3.66 & 17.87 & 3.67 \\
\hline
\end{tabular}

${ }^{*}$ EO: essential oil; ** DI: disease index. 
Table 3. Savory essential oil composition and volatilized compounds in storage cabinet at 1, 14 and 28 days.

\begin{tabular}{|c|c|c|c|c|c|c|c|c|c|c|c|c|c|}
\hline \multirow{3}{*}{ EO * Components } & \multirow{3}{*}{$D I * *(\%)$} & \multicolumn{6}{|c|}{ Savory $10 \%$} & \multicolumn{6}{|c|}{ Savory $1 \%$} \\
\hline & & \multicolumn{2}{|c|}{ T1 } & \multicolumn{2}{|c|}{ T14 } & \multicolumn{2}{|c|}{ T28 } & \multicolumn{2}{|c|}{ T1 } & \multicolumn{2}{|c|}{ T14 } & \multicolumn{2}{|c|}{ T28 } \\
\hline & & ppm & $(\%)$ & ppm & $(\%)$ & ppm & $(\%)$ & ppm & $(\%)$ & ppm & $(\%)$ & ppm & $(\%)$ \\
\hline$\alpha$-Pinene & 0.76 & 4.64 & 0.48 & 16.27 & 0.76 & 12.06 & 0.64 & 1.35 & 0.20 & 2.03 & 0.23 & 3.63 & 0.40 \\
\hline Myrcene & 0.47 & 5.33 & 0.56 & 15.19 & 0.70 & 16.70 & 0.89 & 1.31 & 0.19 & 1.59 & 0.16 & 5.15 & 0.59 \\
\hline$p$-Cymene & 10.63 & 119.89 & 13.71 & 297.20 & 14.17 & 248.17 & 13.62 & 34.46 & 7.43 & 41.12 & 5.78 & 55.77 & 6.96 \\
\hline Eucalyptol & 7.71 & 185.98 & 21.30 & 442.63 & 21.11 & 394.67 & 21.67 & 138.52 & 30.15 & 113.11 & 16.01 & 160.06 & 20.09 \\
\hline$\gamma$-Terpinen & 9.45 & 128.33 & 14.68 & 284.79 & 13.57 & 234.37 & 12.86 & 38.00 & 8.20 & 46.39 & 6.53 & 62.31 & 7.79 \\
\hline trans-Linalool oxide & 1.19 & 11.95 & 1.32 & 42.58 & 2.01 & 51.48 & 2.81 & 2.15 & 0.38 & 9.50 & 1.29 & 12.76 & 1.55 \\
\hline cis-Linalool oxide & 0.86 & 9.49 & 1.04 & 29.57 & 1.39 & 37.81 & 2.05 & 1.63 & 0.26 & 6.31 & 0.83 & 9.31 & 1.12 \\
\hline Linalool & 22.16 & 183.71 & 21.03 & 418.00 & 19.93 & 384.31 & 21.10 & 138.19 & 30.08 & 286.32 & 40.63 & 273.29 & 34.33 \\
\hline Plinol & 0.34 & 4.47 & 0.46 & 12.46 & 0.57 & 13.33 & 0.71 & 2.90 & 0.54 & 6.90 & 0.92 & 7.25 & 0.86 \\
\hline Isoborneol & 1.09 & 10.89 & 1.20 & 29.90 & 1.41 & 31.05 & 1.68 & 7.20 & 1.48 & 18.72 & 2.60 & 18.43 & 2.26 \\
\hline Borneol & 2.24 & 13.44 & 1.49 & 32.25 & 1.52 & 36.66 & 1.99 & 9.48 & 1.98 & 23.08 & 3.22 & 27.94 & 3.46 \\
\hline$\alpha$-Terpineol & 1.36 & 4.51 & 0.47 & 10.31 & 0.47 & 12.11 & 0.64 & 3.64 & 0.70 & 7.27 & 0.97 & 9.71 & 1.17 \\
\hline Carvone & 2.09 & 7.26 & 0.78 & 15.48 & 0.72 & 17.10 & 0.92 & 8.24 & 1.70 & 16.99 & 2.35 & 16.76 & 2.05 \\
\hline Bornyl acetate & 1.55 & 9.84 & 1.08 & 20.52 & 0.96 & 16.98 & 0.91 & 11.08 & 2.32 & 12.70 & 1.74 & 10.59 & 1.28 \\
\hline Thymol & 10.67 & 1.59 & 0.17 & 6.65 & 0.36 & 9.43 & 0.60 & 1.65 & 0.34 & 4.78 & 0.75 & 8.77 & 1.27 \\
\hline Carvacrol & 13.29 & 1.68 & 0.14 & 10.38 & 0.47 & 11.90 & 0.63 & 2.19 & 0.38 & 6.41 & 0.85 & 11.66 & 1.41 \\
\hline
\end{tabular}

${ }^{*}$ EO: essential oil; ${ }^{* *}$ DI: disease index. 
In storage room atmosphere, where savory diffusors at $10 \%$ were used, linalool and eucalyptol were the main components at the three sampling times. On the contrary, thymol and carvacrol in chambers showed a significant decrease compared to the pure EO, in fact they were present at $0.14 \%$ to $0.63 \%$ for carvacrol and at $0.17 \%$ to $0.60 \%$ for thymol at the beginning and at the end of the trial, respectively.

These results showed that antifungal components of thyme and savory essential oils increased during storage, but they were a low fraction of the volatile organic compounds in the storage chambers, compared to their concentration in pure EO. For this reason, diffusors could be considered effective in a slow release of vapor EOs.

The antifungal activity of thyme and savory EO in vapor phase was demonstrated by performing an in vitro test in agar plate, where M. fructicola and B. cinerea could germinate in an atmosphere with the same concentration present in the cabinet (Figure 2).

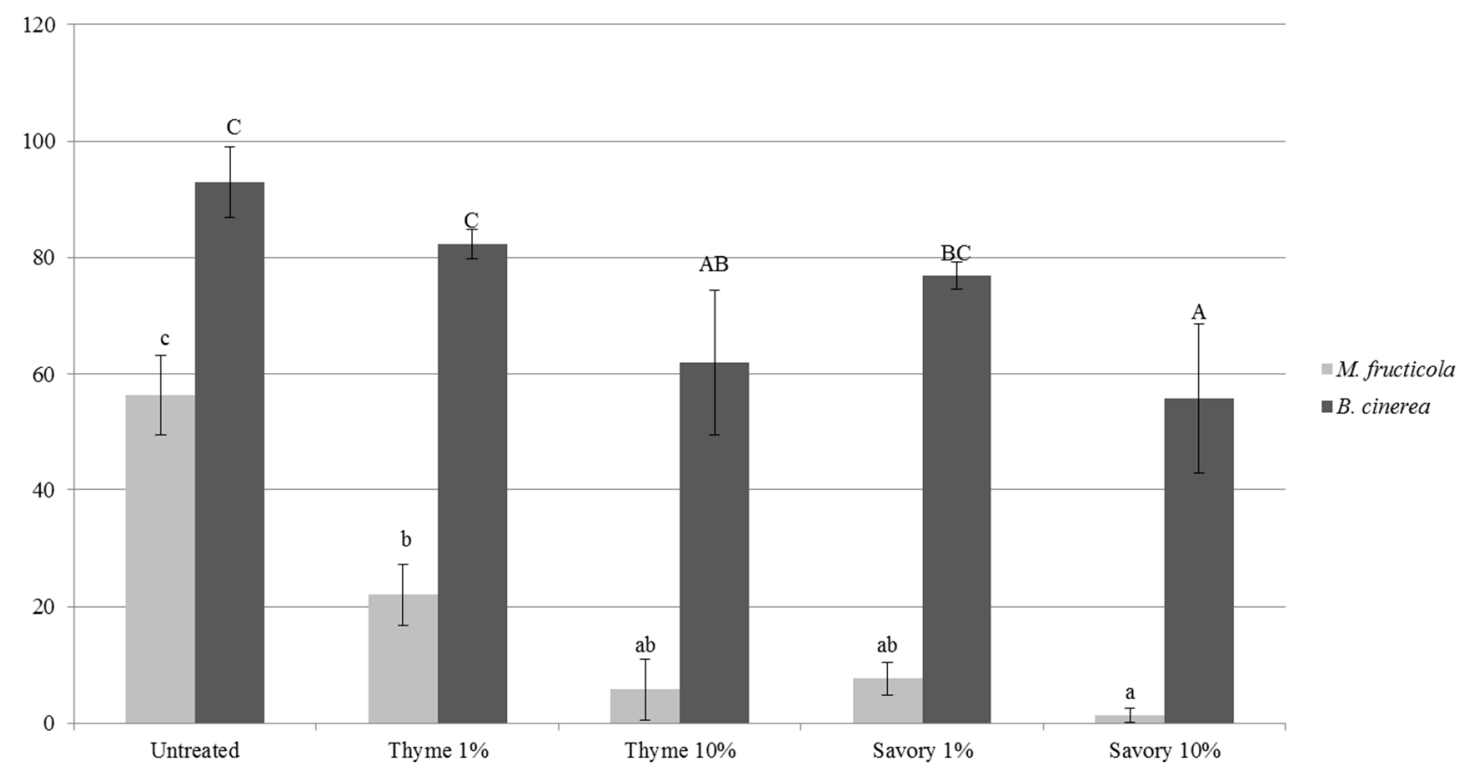

Figure 2. M. fructicola (gray columns) and B. cinerea conidial germination percentage (black columns) after biofumigation without direct contact with essential oil in vitro. Conidial germination was assessed after $20 \mathrm{~h}$ for $B$. cinerea and $36 \mathrm{~h}$ for $M$. fructicola at $20^{\circ} \mathrm{C}$. Values of the same pathogen, followed by the same letter, are not statistically different by Tukey's Test $(p<0.05)$.

The antifungal effects depended on the type and concentration of EO, and on the pathogen species [17]. M. fructicola was almost completely inhibited by savory vapors at $10 \%$. Thyme essential oil vapors led to $40 \%$ decrease of conidial germination rate. As expected, vapor treatments were more effective in vitro, when EO concentration increased. All the EO treatments caused a significant decrease of germ tube length with respect to the untreated control (Table 4).

Table 4. Essential oil vapors effect on germ tube length in vitro measured after $36 \mathrm{~h}$ at $20{ }^{\circ} \mathrm{C}$ for M. fructicola and $20 \mathrm{~h}$ at $20^{\circ} \mathrm{C}$ for B. cinerea.

\begin{tabular}{ccc}
\hline & M. fructicola Germ Tube $(\mu \mathrm{m})$ & B. cinerea Germ Tube $(\mu \mathrm{m})$ \\
\hline Untreated control & $10.5^{\mathrm{b}}$ & $212.7^{\mathrm{c}}$ \\
Thyme 1\% & $8.0^{\mathrm{a}}$ & $208.5^{\mathrm{bc}}$ \\
Thyme 10\% & $6.5^{\mathrm{a}}$ & $190.9^{\mathrm{ab}}$ \\
Savory 1\% & $8.6^{\mathrm{a}}$ & $165.6^{\mathrm{ab}}$ \\
Savory 10\% & $5.8^{\mathrm{a}}$ & $109.9^{\mathrm{a}}$ \\
\hline
\end{tabular}

Values of the same column, followed by the same letter within each column, are not statistically different by Tukey's Test $(p<0.05)$. 
Previous results showed that thymol vapors inhibited $M$. fructicola mycelial growth and were fatal for conidia viability; the fumigated spores resulted shrunken and with collapsed protoplasts [38]. Thymol is able to crystallize on the outer surface of cell walls and exposed fungal structures were characterized by disrupted cell membranes and disorganized cytoplasmic organelles, reducing to $50 \%$ conidial viability at $2 \mu \mathrm{g} / \mathrm{mL}$ and to $17-23 \%$ when thymol was applied at $8 \mu \mathrm{g} / \mathrm{mL}$ [39].

B. cinerea is much less sensitive to essential oil antimicrobial activity [40]. In our experiments, the fungus confirmed to be less sensitive to EO vapors, compared to M. fructicola and maximum reduction of conidial germination was $40.1 \%$ for savory vapors at $10 \%$. Germ tube length of $B$. cinerea growth was inhibited only by $10 \%$ thyme treatment, while the other treatments were not statistically different from the untreated control.

In vitro tests confirmed the results obtained in fruit: the antimicrobial activity of vapor EOs does not need a direct contact. Moreover, the higher efficacy against $M$. fructicola, compared to $B$. cinerea in vitro explained the higher reduction of brown rot on fruit, accompanied by a higher incidence of gray mold. This effect was particularly evident on peaches. Untreated fruit were affected exclusively by $M$. fructicola, while other pathogens could develop on fumigated fruits by colonizing the niche left empty by the inhibition of M. fructicola. Thanks to the lower sensitivity of B. cinerea to EO vapors, the pathogen could start to develop on fumigated fruit causing gray rots.

Besides the efficacy against the postharvest rots, weight loss, color, total soluble solids, titratable acidity, ascorbic acid and carotenoids contents were analyzed during fruit storage.

The use of thyme EO reduced weight loss particularly on peaches (Table 5).

Table 5. Weight loss $(\% w / w)$ of nectarines 'Sweet Red' and peaches 'Vista Rich'.

\begin{tabular}{|c|c|c|c|c|c|c|}
\hline \multirow{3}{*}{ Fruit } & \multirow{3}{*}{ Treatments } & \multicolumn{5}{|c|}{ Weight Loss $(\%$ w/w) } \\
\hline & & \multicolumn{5}{|c|}{ Days of Storage } \\
\hline & & 7 & 14 & 21 & 28 & 5 Shelf Life \\
\hline Nectarines & Untreated control & $0.55^{\mathrm{ab}}$ & $0.82^{a}$ & $1.06^{\mathrm{a}}$ & $1.29^{a}$ & $10.7^{\mathrm{a}}$ \\
\hline Nectarines & Thyme 1\% & $0.80^{\mathrm{a}}$ & $1.00^{\mathrm{a}}$ & $1.20^{\mathrm{a}}$ & $1.35^{\mathrm{a}}$ & $9.01^{b}$ \\
\hline Nectarines & Thyme 10\% & $0.69^{a b}$ & $0.85^{\mathrm{a}}$ & $1.04^{\mathrm{a}}$ & $1.20^{\mathrm{a}}$ & $9.22^{a b}$ \\
\hline Nectarines & Savory $1 \%$ & $0.55^{\mathrm{ab}}$ & $0.79^{a}$ & $1.00^{\mathrm{a}}$ & $1.15^{\mathrm{a}}$ & $9.46^{\mathrm{ab}}$ \\
\hline Nectarines & Savory $10 \%$ & $0.49^{b}$ & $0.72^{b}$ & $0.94^{\mathrm{a}}$ & $1.16^{\mathrm{a}}$ & $9.49^{a b}$ \\
\hline Peaches & Untreated control & $1.55^{\mathrm{a}}$ & $1.91^{\mathrm{a}}$ & $2.16^{\mathrm{a}}$ & $2.51^{\mathrm{a}}$ & - \\
\hline Peaches & Thyme $1 \%$ & $1.31^{\mathrm{a}}$ & $1.42^{\mathrm{c}}$ & $1.72^{\mathrm{c}}$ & $1.81^{\mathrm{c}}$ & - \\
\hline Peaches & Thyme $10 \%$ & $0.99^{b}$ & $1.26^{\mathrm{d}}$ & $1.49^{\mathrm{d}}$ & $1.61^{\mathrm{c}}$ & - \\
\hline Peaches & Savory 1\% & $1.39^{\mathrm{a}}$ & $1.73^{\mathrm{b}}$ & $1.97^{b}$ & $2.10^{\mathrm{b}}$ & - \\
\hline Peaches & Savory $10 \%$ & $1.54^{\mathrm{a}}$ & $1.77^{\mathrm{ab}}$ & $1.97^{b}$ & $2.10^{b}$ & - \\
\hline
\end{tabular}

Mean values followed by the same letter within each column are not significantly different by Tukey's Test at $p \leq 0.05$.

Untreated control showed the highest weight loss at the end of the storage in both trials. The efficacy of EO fumigation could be related to the formation of a coating on the fruit surface that modifies gas permeation, reducing respiration rate and water loss. Our results were in agreement with previous experiments on cherries [41], grapes [42], and peaches [43] treated with eugenol, thymol, menthol and cinnamon vapors. The EO vapors were shown to reduce the dehydration process or weight loss in fruit [44]. Other studies showed that the application of essential oils together with edible coatings could reduce the water loss [45]. There are few references reporting the effect of EO treatments on fruit color. Here, ground and overcolor lightness and hue angle were monitored during storage. The lightness values of the nectarines decreased both in ground and overcolor during cold storage (Table 6).

The differences among the treatments were observed at the end of the shelf life, when treated samples showed higher values than the untreated control. Regarding peaches, no differences among the treatments were detected (Table 7). 
Table 6. Color parameters (lightness and hue angle) in nectarines with different treatments during storage.

\begin{tabular}{|c|c|c|c|c|c|c|c|c|}
\hline \multirow{2}{*}{ Color Parameters } & \multirow{2}{*}{ Ground or Overcolor } & \multirow{2}{*}{ Treatments } & \multicolumn{6}{|c|}{ Storage Times (Days) } \\
\hline & & & 0 & 7 & 14 & 21 & 28 & 5 Shelf Life \\
\hline \multirow[t]{5}{*}{ Lightness $\left(\mathrm{L}^{*}\right)$} & GC & Untreated control & $68.70^{\mathrm{a}}$ & $67.86^{\mathrm{a}}$ & $67.78^{a}$ & $68.6^{a}$ & $68.28^{a}$ & $63.71^{b}$ \\
\hline & GC & Thyme $1 \%$ & $67.75^{\mathrm{a}}$ & $65.38^{a}$ & $65.64^{\mathrm{a}}$ & $67.57^{\mathrm{a}}$ & $65.97^{a b}$ & $64.96^{\mathrm{ab}}$ \\
\hline & GC & Thyme $10 \%$ & $67.67^{\mathrm{a}}$ & $65.32^{\mathrm{a}}$ & $65.37^{\mathrm{a}}$ & $67.17^{\mathrm{a}}$ & $65.64^{b}$ & $64.07^{\mathrm{ab}}$ \\
\hline & GC & Savory 1\% & $68.79^{a}$ & $65.55^{a}$ & $66.81^{\mathrm{a}}$ & $67.18^{a}$ & $67.67^{a b}$ & $67.75^{\mathrm{a}}$ \\
\hline & GC & Savory $10 \%$ & $68.38^{a}$ & $66.85^{a}$ & $65.79^{a}$ & $67.84^{a}$ & $68.14^{\mathrm{ab}}$ & $66.78^{a b}$ \\
\hline \multirow[t]{5}{*}{ Hue angle (h) } & GC & Untreated control & $82.44^{\mathrm{a}}$ & $86.25^{a}$ & $83.73^{a}$ & $84.12^{\mathrm{a}}$ & $84.25^{\mathrm{a}}$ & $66.16^{a}$ \\
\hline & GC & Thyme $1 \%$ & $80.28^{a}$ & $79.73^{\mathrm{b}}$ & $78.39^{\text {a }}$ & $77.91^{\mathrm{b}}$ & $78.98^{a b}$ & $66.50^{\mathrm{a}}$ \\
\hline & GC & Thyme $10 \%$ & $78.76^{\mathrm{a}}$ & $75.11^{b}$ & $79.01^{\mathrm{a}}$ & $77.74^{b}$ & $78.03^{b}$ & $69.73^{a}$ \\
\hline & GC & Savory $1 \%$ & $81.59^{\mathrm{a}}$ & $79.55^{b}$ & $79.37^{\mathrm{a}}$ & $81.31^{\mathrm{ab}}$ & $81.82^{a b}$ & $70.29^{a}$ \\
\hline & GC & Savory $10 \%$ & $83.24^{\mathrm{a}}$ & $81.47^{a b}$ & $81.43^{a}$ & $81.35^{a b}$ & $77.94^{b}$ & $72.89^{a}$ \\
\hline \multirow[t]{5}{*}{ Lightness $\left(\mathrm{L}^{*}\right)$} & OC & Untreated control & $40.20^{\mathrm{a}}$ & $48.11^{\mathrm{a}}$ & $41.64^{\mathrm{a}}$ & $38.34^{\mathrm{b}}$ & $39.79^{\text {a }}$ & $44.19^{a b}$ \\
\hline & OC & Thyme $1 \%$ & $44.73^{a}$ & $46.96^{\mathrm{a}}$ & $39.00^{a b}$ & $42.03^{a}$ & $40.12^{a}$ & $39.63^{b}$ \\
\hline & OC & Thyme $10 \%$ & $40.16^{\mathrm{a}}$ & $42.41^{\mathrm{b}}$ & $37.45^{\mathrm{b}}$ & $42.65^{a}$ & $37.45^{a}$ & $43.93^{\mathrm{ab}}$ \\
\hline & OC & Savory 1\% & $45.20^{\mathrm{a}}$ & $43.14^{b}$ & $37.54^{b}$ & $35.68^{b}$ & $38.76^{\mathrm{a}}$ & $48.14^{\mathrm{a}}$ \\
\hline & OC & Savory $10 \%$ & $39.34^{\mathrm{a}}$ & $45.96^{\mathrm{ab}}$ & $37.81^{\mathrm{ab}}$ & $37.54^{\mathrm{b}}$ & $36.73^{a}$ & $43.72^{\mathrm{ab}}$ \\
\hline \multirow[t]{5}{*}{ Hue angle (h) } & OC & Untreated control & $20.28^{a}$ & $42.58^{\mathrm{a}}$ & $33.75^{a}$ & $27.32^{b}$ & $30.88^{a}$ & $29.58^{a b}$ \\
\hline & OC & Thyme $1 \%$ & $33.94^{\mathrm{a}}$ & $41.84^{\mathrm{ab}}$ & $32.78^{a}$ & $34.52^{a}$ & $31.80^{\mathrm{a}}$ & $20.80^{c}$ \\
\hline & OC & Thyme $10 \%$ & $25.68^{a}$ & $36.69^{b}$ & $31.23^{\mathrm{a}}$ & $29.67^{b}$ & $28.32^{\mathrm{a}}$ & $28.27^{b c}$ \\
\hline & OC & Savory 1\% & $33.49^{\mathrm{a}}$ & $38.3^{a b}$ & $30.79^{a}$ & $27.46^{\mathrm{b}}$ & $29.16^{\mathrm{a}}$ & $36.20^{a}$ \\
\hline & OC & Savory $10 \%$ & $25.19^{a}$ & $40.64^{\mathrm{ab}}$ & $33.05^{\mathrm{a}}$ & $28.48^{b}$ & $27.07^{\mathrm{a}}$ & $27.47^{b c}$ \\
\hline
\end{tabular}

Nectarines 'Sweet Red': GC: ground color; OC: over color. Mean values followed by the same letter within each column are not significantly different by Tukey's Test at $p \leq 0.05$. Letters in the same column are used to compare the treatment influence. 
Table 7. Color parameters (lightness and hue angle) in peaches with different treatments during storage.

\begin{tabular}{|c|c|c|c|c|c|c|c|}
\hline \multirow{2}{*}{ Color Parameters } & \multirow{2}{*}{ Ground or Overcolor } & \multirow{2}{*}{ Treatments } & \multicolumn{5}{|c|}{ Storage Times (Days) } \\
\hline & & & 0 & 7 & 14 & 21 & 28 \\
\hline \multirow[t]{5}{*}{ Lightness $\left(\mathrm{L}^{*}\right)$} & GC & Untreated control & $49.16^{\mathrm{a}}$ & $49.30^{a}$ & $49.42^{b}$ & $54.45^{\mathrm{a}}$ & $53.44^{\mathrm{a}}$ \\
\hline & GC & Thyme $1 \%$ & $49.42^{\mathrm{a}}$ & $50.50^{\mathrm{a}}$ & $51.72^{a b}$ & $54.24^{\mathrm{a}}$ & $52.97^{\mathrm{a}}$ \\
\hline & GC & Thyme $10 \%$ & $49.43^{a}$ & $51.55^{\mathrm{a}}$ & $51.52^{\mathrm{ab}}$ & $52.96^{\mathrm{a}}$ & $53.61^{\mathrm{a}}$ \\
\hline & GC & Savory $1 \%$ & $49.62^{\mathrm{a}}$ & $52.08^{a}$ & $54.46^{\mathrm{ab}}$ & $55.38^{\mathrm{a}}$ & $55.20^{\mathrm{a}}$ \\
\hline & GC & Savory $10 \%$ & $49.20^{\mathrm{a}}$ & $51.07^{\mathrm{a}}$ & $54.46^{\mathrm{a}}$ & $54.04^{\mathrm{a}}$ & $52.85^{\mathrm{a}}$ \\
\hline \multirow[t]{5}{*}{ Hue angle (h) } & GC & Untreated control & $43.12^{a}$ & $57.21^{a}$ & $60.76^{\mathrm{b}}$ & $68.78^{a}$ & $65.62^{\mathrm{a}}$ \\
\hline & GC & Thyme $1 \%$ & $46.06^{a}$ & $63.87^{a}$ & $67.13^{a b}$ & $70.48^{a}$ & $64.16^{\mathrm{a}}$ \\
\hline & GC & Thyme $10 \%$ & $52.56^{\mathrm{a}}$ & $60.00^{\mathrm{a}}$ & $68.88^{a b}$ & $66.61^{\mathrm{a}}$ & $66.40^{\mathrm{a}}$ \\
\hline & GC & Savory $1 \%$ & $52.84^{\mathrm{a}}$ & $65.96^{\mathrm{a}}$ & $71.44^{\mathrm{a}}$ & $75.48^{\mathrm{a}}$ & $71.30^{\mathrm{a}}$ \\
\hline & GC & Savory $10 \%$ & $48.81^{\mathrm{a}}$ & $59.94^{\mathrm{a}}$ & $69.11^{a b}$ & $69.25^{\mathrm{a}}$ & $62.33^{a}$ \\
\hline \multirow[t]{5}{*}{ Lightness $\left(\mathrm{L}^{*}\right)$} & OC & Untreated control & $37.98^{\mathrm{a}}$ & $41.38^{c}$ & $43.23^{a}$ & $45.56^{\mathrm{a}}$ & $45.08^{\mathrm{a}}$ \\
\hline & OC & Thyme $1 \%$ & $36.56^{\mathrm{a}}$ & $44.20^{\mathrm{ab}}$ & $44.28^{a}$ & $43.57^{\mathrm{a}}$ & $45.39^{\mathrm{a}}$ \\
\hline & OC & Thyme $10 \%$ & $34.24^{\mathrm{a}}$ & $44.79^{a b}$ & $43.09^{\mathrm{a}}$ & $45.12^{\mathrm{a}}$ & $44.14^{\mathrm{a}}$ \\
\hline & OC & Savory 1\% & $34.86^{a}$ & $45.30^{\mathrm{a}}$ & $42.15^{\mathrm{a}}$ & $43.93^{a}$ & $45.73^{\mathrm{a}}$ \\
\hline & OC & Savory $10 \%$ & $33.79^{\mathrm{a}}$ & $42.77^{b c}$ & $43.54^{a}$ & $43.74^{\mathrm{a}}$ & $46.35^{\mathrm{a}}$ \\
\hline \multirow[t]{5}{*}{ Hue angle (h) } & OC & Untreated control & $15.22^{\mathrm{a}}$ & $35.06^{b c}$ & $36.60^{a}$ & $36.52^{a}$ & $34.26^{\mathrm{a}}$ \\
\hline & OC & Thyme $1 \%$ & $18.45^{\mathrm{a}}$ & $39.76^{a}$ & $36.98^{\text {a }}$ & $35.14^{\mathrm{a}}$ & $37.52^{\mathrm{a}}$ \\
\hline & OC & Thyme $10 \%$ & $17.25^{\mathrm{a}}$ & $37.91^{\mathrm{ab}}$ & $35.01^{a}$ & $37.18^{a}$ & $34.56^{\mathrm{a}}$ \\
\hline & OC & Savory $1 \%$ & $22.42^{\mathrm{a}}$ & $38.01^{a b}$ & $33.45^{\mathrm{a}}$ & $35.07^{\mathrm{a}}$ & $36.34^{\mathrm{a}}$ \\
\hline & OC & Savory $10 \%$ & $17.88^{\mathrm{a}}$ & $32.04^{c}$ & $35.02^{\text {a }}$ & $34.98^{\mathrm{a}}$ & $35.70^{\mathrm{a}}$ \\
\hline
\end{tabular}

Peaches 'Vista Rich'. GC: ground color; OC: over color. Mean values followed by the same letter within each column are not significantly different by Tukey's Test at $p \leq 0.05$. Lowercase letters $(a, b)$ in the same column are used to compare the treatment influence. 
The hue angle is a measure of ripening. In general, the hue angle values of the ground color decrease during postharvest storage, as fruit become yellow. In nectarines, the hue angle remained stable during storage, but some differences among treatments were observed and nectarines treated with EOs were yellower than the control fruit. In peaches, the ground color became yellower during storage as expected, but no differences among treatments were observed. In conclusion, the use of EOs had no negative effect on fruit color. The color variations were connected with the natural ripening process and were slowed down by cold storage.

EO vapors influenced also carotenoid content preserving the amount of these antioxidant compounds in fumigated fruit. Generally, carotenoids decrease during storage. They are photoand heat-sensitive and tend to oxidize if they are not protected from light and atmosphere [46]. In nectarines, only untreated control and fruit treated with savory EO at $1 \%$ showed a significant decrease in total carotenoid content during storage, while carotenoid amounts remained stable in the other fumigated fruit (Figure 3).

(a)

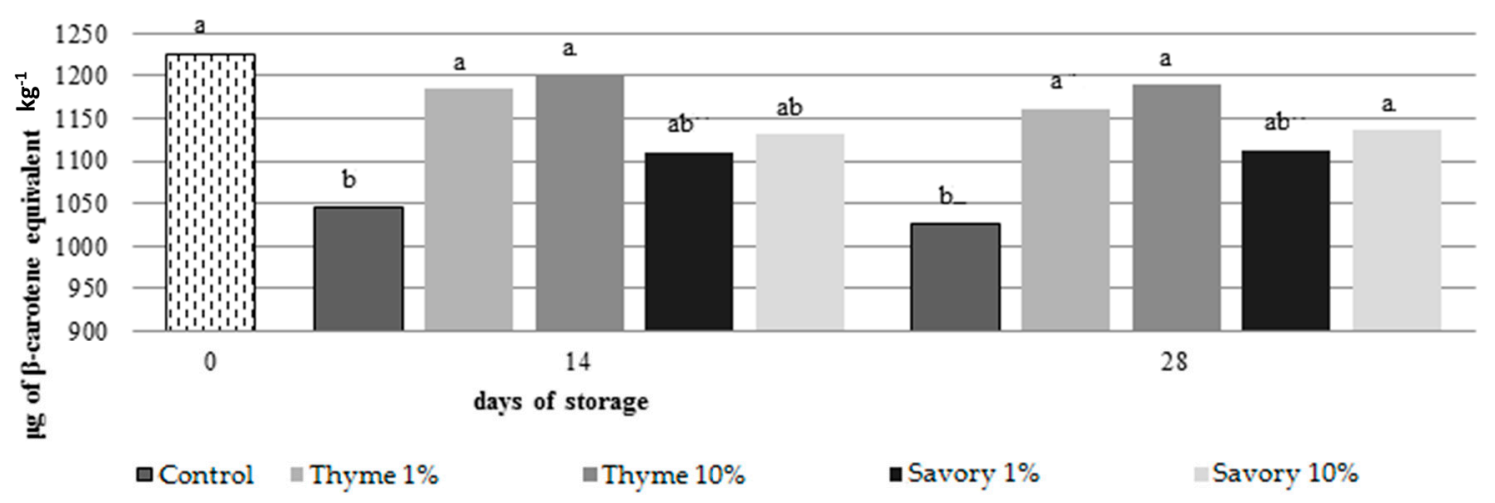

(b)

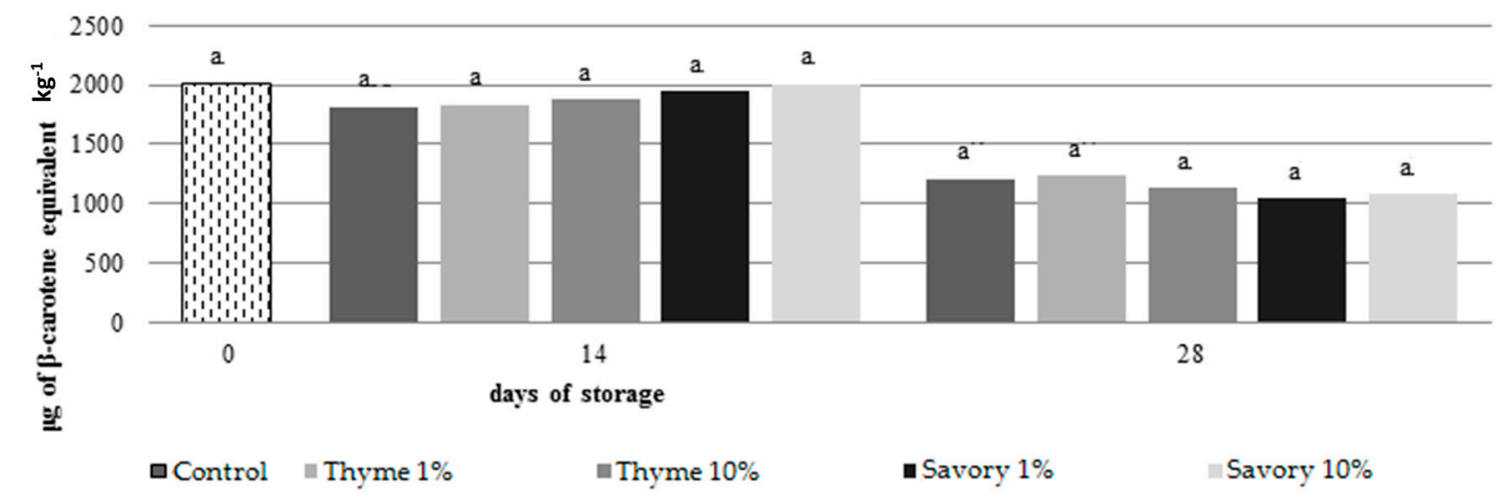

Figure 3. Total content of carotenoids in nectarines 'Sweet Red' (a) and peaches 'Vista Rich' (b) after 0,14 and 28 days of cold storage. Mean values at the same time followed by the same letter are not significantly different by Tukey's Test at $p \leq 0.05$.

At the end of the trials, fruit treated with thyme at $1 \%$ and $10 \%$ had the highest amount of carotenoids (1189 $\mu \mathrm{g} / \mathrm{kg}$ and $1162 \mu \mathrm{g} / \mathrm{kg}$, respectively).

Both on nectarines and peaches, untreated fruit showed the lowest AA content at the end of cold storage resulting statistically different from treated fruit (Figure 4). 
(a)

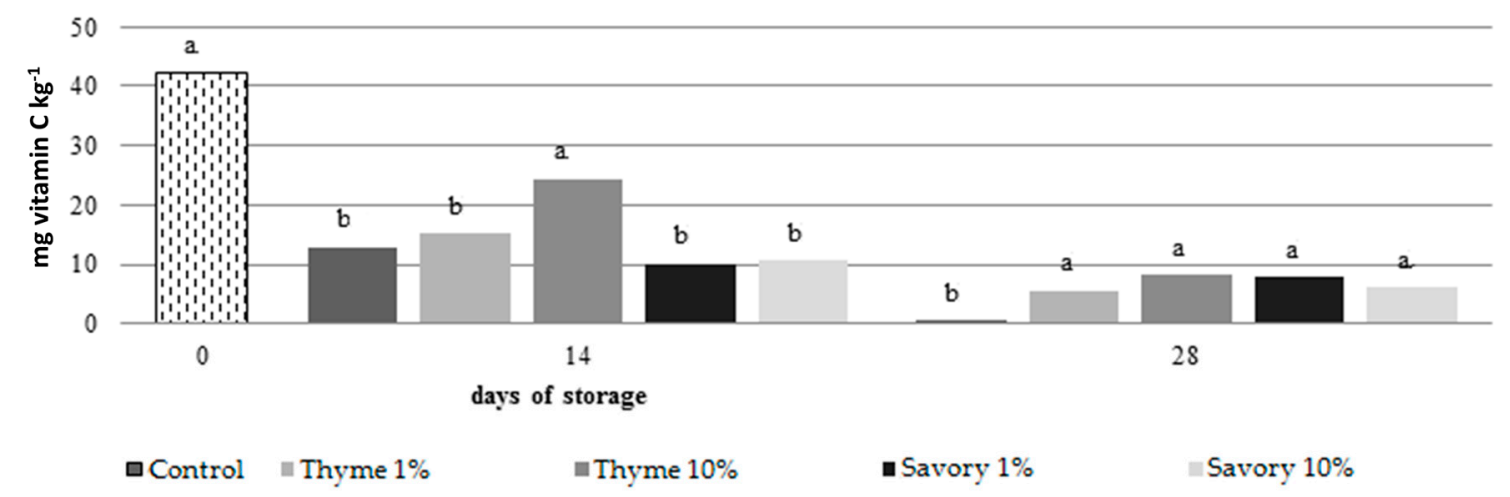

(b)

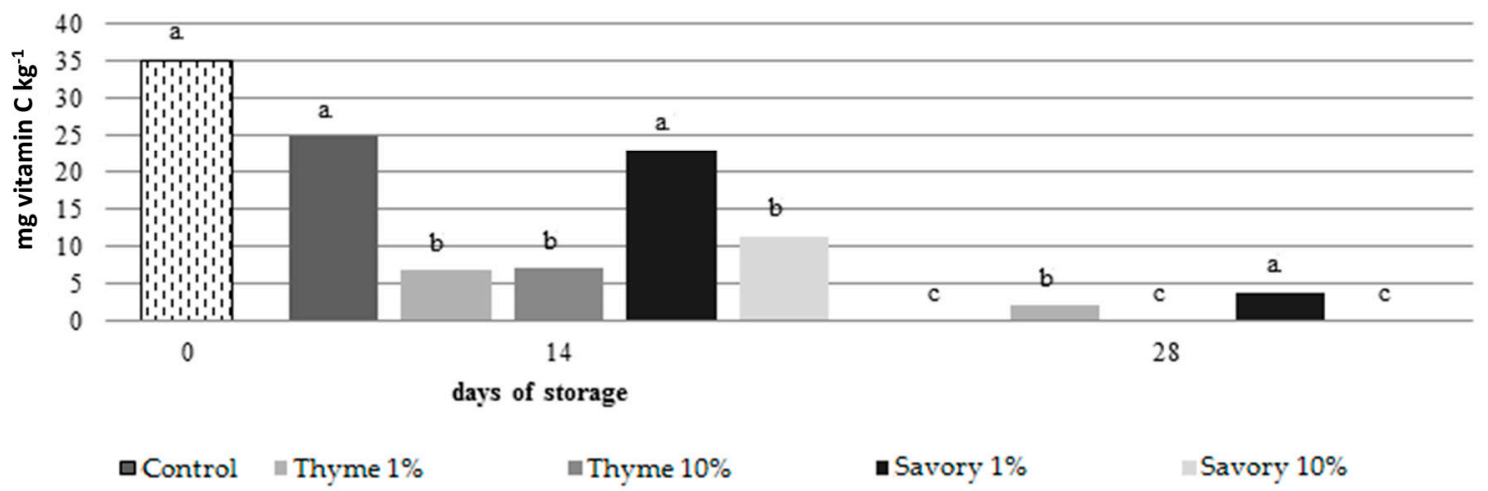

Figure 4. Total content of vitamin C (ascorbic acid and dehydroascorbic acid) in nectarines 'Sweet Red' (a) and peaches 'Vista Rich' (b) after 0, 14 and 28 days of cold storage. Mean values at the same time followed by the same letter are not significantly different by Tukey's Test at $p \leq 0.05$.

The use of EOs preserved ascorbic acid contents, without showing statistical differences between the treatments. In peaches, fruit fumigated with savory and thyme essential oils at $1 \%$ maintained the grater ascorbic acid content at the end of the trial.

The ascorbic acid content decreased significantly during cold storage, as expected, and the EO influenced the process. The decrease in ascorbic acid could be explained by the chemical properties and metabolic functions of AA in the plant cell [47]. AA and dehydroascorbic acid (DHAA) are important antioxidants and are used against the reactive oxygen species, produced naturally by the metabolism of vegetal cells, and accumulated during storage [48].

The use of EOs led to a delay in the loss of total carotenoids content and AA in the pulp. Some EOs (thymol, menthol and eugenol) have shown antioxidant activity and free radical scavenging capability [49]. These effects could explain the EO efficacy in reducing the loss of nutrients. Valero et al. (2006) [50] suggested that the addition of thymol slowed the AA loss in grape. Nevertheless, different effects of EOs on total carotenoids content between nectarines and peaches were evident. The EOs were more effective on the metabolism of nectarines, while in peaches the action of the EOs was less evident.

\section{Conclusions}

Savory and thyme essential oil vapors demonstrated a high antifungal activity against $M$. fructicola even at low concentrations. B. cinerea was less sensitive to EO vapors and could develop when M. fructicola was inhibited. EO concentrations require a careful optimization depending on fruit cultivars. Although in in vitro tests the efficacy is directly correlated with EO concentrations, 
when applied on fruit EO vapors could have phytotoxic effects, which reduce treatment efficacy. EO vapors did not influence the overall quality of the fruit, but showed a positive effect in maintaining nutritional values avoiding ascorbic acid and carotenoids oxidation, preserving the quality of the final product. The application of thyme and savory essential oils represents a promising tool for reducing postharvest losses and preserving quality in peaches and nectarines.

Acknowledgments: Work carried out with a contribution of the LIFE financial instrument of the European Union for the project "Low pesticide IPM in sustainable and safe fruit production" (Contract No. LIFE13 $\mathrm{ENV} / \mathrm{HR} / 000580)$.

Author Contributions: Davide Spadaro, Maria Lodovica Gullino, Valentina Chiabrando and Giovanna Giacalone conceived and designed the experiments; Karin Santoro performed the phytopathological, microbiological and molecular experiments, Marco Maghenzani performed fruit quality analyses, Pietro Bosio performed the gas chromatography analyses, Karin Santoro, Marco Maghenzani and Davide Spadaro wrote the paper.

Conflicts of Interest: The authors declare no conflict of interest. The founding sponsors had no role in the design of the study; in the collection, analyses, or interpretation of data; in the writing of the manuscript, and in the decision to publish the results.

\section{References}

1. Di Vaio, C.; Graziani, G.; Marra, L.; Cascone, A.; Ritieni, A. Antioxidant capacities, carotenoids and polyphenols evaluation of fresh and refrigerated peach and nectarine cultivars from Italy. Eur. Food Res. Technol. 2008, 227, 1225-1231. [CrossRef]

2. Gil, M.I.; Tomas-Barberan, F.A.; Hess-Pierce, B.; Kader, A.A. Antioxidant capacities, phenolic compounds, carotenoids, and vitamin C contents of nectarine, peach, and plum cultivars from California. J. Agric. Food Chem. 2002, 50, 4976-4982. [CrossRef] [PubMed]

3. Munera, S.; Amigo, J.M.; Blasco, J.; Cubero, S.; Talens, P.; Aleixos, N. Ripeness monitoring of two cultivars of nectarine using VIS-NIR hyperspectral reflectance imaging. J. Food Eng. 2017, 214, 29-39. [CrossRef]

4. Food and Agricultural Organisation of the United Nations. Available online: http://faostat3.fao.org/faostatgateway/go/to/home/E (accessed on 29 December 2017).

5. García-Parra, J.; González-Cebrino, F.; Delgado, J.; Lozano, M.; Hernández, T.; Ramírez, R. Effect of thermal and high-pressure processing on the nutritional value and quality attributes of a Nectarine Purée with industrial origin during the refrigerated storage. J. Food Sci. 2011, 76, 618-625. [CrossRef] [PubMed]

6. Peano, C.; Giacalone, G.; Bounous, G. Changes in fruit quality of peache and nectarine from transport to shelf. ISHS Acta Hortic. 2000, 553, 739-740.

7. Karabulut, O.A.; Cohen, L.; Wiess, B.; Daus, A.; Lurie, S.; Droby, S. Control of brown rot and blue mold of peach and nectarine by short hot water brushing and yeast antagonists. Postharvest Biol. Technol. 2002, 24, 103-111. [CrossRef]

8. Zhang, H.; Zheng, X.; Yu, T. Biological control of postharvest diseases of peach with Cryptococcus laurentii. Food Control 2007, 18, 287-291. [CrossRef]

9. Larena, I.; Torres, R.; De Cal, A.; Liñán, M.; Melgarejo, P.; Domenichini, P.; Bellini, A.; Mandrin, J.F.; Lichou, J.; De Eribe, X.O.; et al. Biological control of postharvest brown rot (Monilinia spp.) of peaches by field applications of Epicoccum nigrum. Biol. Control 2005, 32, 305-310. [CrossRef]

10. Spadoni, A.; Guidarelli, M.; Sanzani, S.M.; Ippolito, A.; Mari, M. Influence of hot water treatment on brown rot of peach and rapid fruit response to heat stress. Postharvest Biol. Technol. 2014, 94, 66-73. [CrossRef]

11. Cindi, M.D.; Shittu, T.; Sivakumar, D.; Bautista-Baños, S. Chitosan boehmite-alumina nanocomposite films and thyme oil vapour control brown rot in peaches (Prunus persica L.) during postharvest storage. Crop Prot. 2015, 72, 127-131. [CrossRef]

12. Spadoni, A.; Neri, F.; Mari, M. Physical and chemical control of postharvest diseases. In Advances in Postharvest Fruit and Vegetable Technology Contemporary Food Engineering; Wills, R.B.H., Golding, J.B., Eds.; CRC Press: Boca Raton, FL, USA, 2016; pp. 98-102, ISBN 9781482216974.

13. Mari, M.; Bautista-Banos, S.; Sivakumar, D. Decay control in the postharvest system: Role of microbial and plant volatile organic compounds. Postharvest Biol. Technol. 2016, 122, 70-81. [CrossRef] 
14. Spadaro, D.; Sabetta, W.; Acquadro, A.; Portis, E.; Garibaldi, A.; Gullino, M.L. Use of AFLP for differentiation of Metschnikowia pulcherrima strains for postharvest disease biological control. Microbiol. Res. 2008, 163, 523-530. [CrossRef] [PubMed]

15. Burt, S. Essential oils: Their antibacterial properties and potential applications in foods-A review. Int. J. Food Microbiol. 2004, 94, 223-253. [CrossRef] [PubMed]

16. Bakkali, F.; Averbeck, S.; Averbeck, D.; Idaomar, M. Biological effects of essential oils-A review. Food Chem. Toxicol. 2008, 46, 446-475. [CrossRef] [PubMed]

17. Lopez-Reyes, J.G.; Spadaro, D.; Prelle, A.; Garibaldi, A.; Gullino, M.L. Efficacy of plant essential oils on postharvest control of rots caused by fungi on different stone fruits in vivo. J. Food Prot. 2013, 76, 631-639. [CrossRef] [PubMed]

18. Daferera, D.J.; Ziogas, B.N.; Polissiou, M.G. GC-MS analysis of essential oils from some Greek aromatic plants and their fungitoxicity on Penicillium digitatum. J. Agric. Food Chem. 2000, 48, 2576-2581. [CrossRef] [PubMed]

19. Barrera-Nacha, L.L.; Bautista-Banos, S.; Flores-Moctezuma, H.E.; Estudillo, A.R. Efficacy of essential oils on the conidial germination, growth of Collectrichum gleosporioides (Penz.) Penz. and Sacc and control of postharvest disease in papaya (Carica papaya L.). Plant Pathol. 2008, 7, 1-5.

20. Spadaro, D.; Gullino, M.L. Use of essential oils to control postharvest rots on pome and stone fruit. In Post-Harvest Pathology; Prusky, D., Gullino, M.L., Eds.; Springer International Publishing: Cham, Switzerland, 2014; pp. 101-110, ISBN 978-3-319-07701-7.

21. Lopez-Reyes, J.G.; Spadaro, D.; Gullino, M.L.; Garibaldi, A. Efficacy of plant essential oils on postharvest control of rot caused by fungi on four cultivars of apples in vivo. Flavour Fragr. J. 2010, 25, 171-177. [CrossRef]

22. Elshafie, H.S.; Camele, I. Investigating the effects of plant essential oils on postharvest fruit decay. In Fungal Pathogenicity; InTech: London, UK, 2016; pp. 83-98, ISBN 978-953-51-2393-4.

23. Mehra, L.K.; MacLean, D.D.; Shewfelt, R.L.; Smith, K.C.; Scherm, H. Effect of postharvest biofumigation on fungal decay, sensory quality, and antioxidant levels of blueberry fruit. Postharvest Biol. Technol. 2013, 85, 109-115. [CrossRef]

24. Plaza, P.; Torres, R.; Usall, J.; Lamarca, N.; Vinas, I. Evaluation of the potential of commercial post-harvest application of essential oils to control citrus decay. J. Hortic. Sci. Biotechnol. 2004, 79, 935-940. [CrossRef]

25. Sciences, B.; Ziedan, E.H.E.; Farrag, E.S.H. Fumigation of peach fruits with essential oils to control postharvest decay. Res. J. Agric. Biol. Sci. 2008, 4, 512-519.

26. Sarkhosh, A.; Vargas, A.I.; Schaffer, B.; Palmateer, A.J.; Lopez, P.; Soleymani, A.; Farzaneh, M. Postharvest management of anthracnose in avocado (Persea americana Mill.) fruit with plant-extracted oils. Food Packag. Shelf Life 2017, 12, 16-22. [CrossRef]

27. Šegvić Klarić, M.; Kosalec, I.; Mastelić, J.; Piecková, E.; Pepeljnak, S. Antifungal activity of thyme (Thymus vulgaris L.) essential oil and thymol against moulds from damp dwellings. Lett. Appl. Microbiol. 2007, 44, 36-42. [CrossRef] [PubMed]

28. Glass, N.L.; Donaldson, G.C. Development of primer sets designed for use with the PCR to amplify conserved genes from filamentous ascomycetes. Appl. Environ. Microbiol. 1995, 61, 1323-1330. [PubMed]

29. Talcott, S.T.; Howard, L.R. Phenolic autoxidation is responsible for color degradation in processed carrot puree. J. Agric. Food Chem. 1999, 47, 2109-2115. [CrossRef] [PubMed]

30. Sánchez-Moreno, C.; Plaza, L.; De Ancos, B.; Cano, M. Vitamin C, Provitamin A carotenoids, and other carotenoids in high pressurized orange juice during refrigerated storage. J. Agric. Food Chem. 2003, 51, 647-653. [CrossRef] [PubMed]

31. Gonzàlez-Molina, E.; Moreno, D.A.; Garcia-Viguera, C. Genotype and harvest time influence the phytochemical quality of fino lemon juice (Citrus limon (L.) Burm. F.) for industrial use. J. Agric. Food Chem. 2008, 56, 1669-1675. [CrossRef] [PubMed]

32. Mari, M.; Martini, C.; Guidarelli, M.; Neri, F. Postharvest biocontrol of Monilinia laxa, Monilinia fructicola and Monilinia fructigena on stone fruit by two Aureobasidium pullulans strains. Biol. Control 2012, 60, 132-140. [CrossRef]

33. Pellegrino, C.; Gullino, M.L.; Garibaldi, A.; Spadaro, D. First report of brown rot of stone fruit caused by Monilinia fructicola in Italy. Plant Dis. 2009, 93, 668. [CrossRef]

34. Babagoli, M.A.; Behdad, E. Effects of three essential oils on the growth of the fungus Alternaria solani. J. Res. Agric. Sci. 2012, 8, 45-57. 
35. Fourie, J.F.; Holz, G. Initial infection processes by Botrytis cinerea on nectarine and plum fruit and the development of decay. Phytopathology 1995, 85, 82-87. [CrossRef]

36. Lazar-Baker, E.E.; Hetherington, S.D.; Ku, V.V.; Newman, S.M. Evaluation of commercial essential oil samples on the growth of postharvest pathogen Monilinia fructicola (G. Winter) Honey. Lett. Appl. Microbiol. 2011, 52, 227-232. [CrossRef] [PubMed]

37. Chu, C.; Liu, W.; Zhou, T.; Station, V.; Protection, S.C. Fumigation of sweet cherries with thymol and acetic acid to reduce postharvest brown rot and blue mold rot. Fruits 2001, 56, 123-130. [CrossRef]

38. Liu, W.T.; Chu, C.L.; Zhou, T. Thymol and acetic acid vapors reduce postharvest brown rot of apricots and plums. HortScience 2002, 37, 151-156.

39. Svircev, A.M.; Smith, R.J.; Zhou, T.; Hernadez, M.; Liu, W.; Chu, C.L. Effects of thymol fumigation on survival and ultrastracture of Monilinia fructicola. Postharvest Biol. Technol. 2007, 45, 228-233. [CrossRef]

40. Arrebola, E.; Sivakumar, D.; Bacigalupo, R.; Korsten, L. Combined application of antagonist Bacillus amyloliquefaciens and essential oils for the control of peach postharvest diseases. Crop Prot. 2010, 29, 369-377. [CrossRef]

41. Serrano, M.; Martínez-Romero, D.; Castillo, S.; Guillén, F.; Valero, D. The use of natural antifungal compounds improves the beneficial effect of MAP in sweet cherry storage. Innov. Food Sci. Emerg. Technol. 2005, 6, 115-123. [CrossRef]

42. Martinez-Romero, D.; Guillén, F.; Valverde, J.M.; Bailén, G.; Zapata, P.; Serrano, M.; Castillo, S.; Valero, D. Influence of carvacrol on survival of Botrytis cinerea inoculated in table grapes. Int. J. Food Microbiol. 2007, 115, 144-148. [CrossRef] [PubMed]

43. Montero-Prado, P.; Rodriguez-Lafuente, A.; Nerin, C. Active label-based packaging to extend the shelf-life of "Calanda" peach fruit: Changes in fruit quality and enzymatic activity. Postharvest Biol. Technol. 2011, 60, 211-219. [CrossRef]

44. Sivakumar, D.; Bautista-Baños, S. A review on the use of essential oils for postharvest decay control and maintenance of fruit quality during storage. Crop Prot. 2014, 64, 27-37. [CrossRef]

45. Kraśniewska, K.; Gniewosz, M.; Kosakowska, O.; Cis, A. Preservation of brussels sprouts by pullulan coating containing oregano essential oil. J. Food Prot. 2016, 79, 493-500. [CrossRef] [PubMed]

46. Leong, S.Y.; Oey, I. Effects of processing on anthocyanins, carotenoids and vitamin C in summer fruits and vegetables. Food Chem. 2012, 133, 1577-1587. [CrossRef]

47. Lee, S.K.; Kader, A.A. Preharvest and postharvest factors influencing vitamin C content of horticultural crops. Postharvest Biol. Technol. 2000, 20, 207-220. [CrossRef]

48. Apel, K.; Hirt, H. Reactive oxygen species: Metabolism, oxidative stress, and signal transduction. Annu. Rev. Plant Biol. 2004, 55, 373-399. [CrossRef] [PubMed]

49. Wang, C.Y.; Wang, S.Y.; Yin, J.J.; Parry, J.; Yu, L.L. Enhancing antioxidant, antiproliferation, and free radical scavenging activities in strawberries with essential oils. J. Agric. Food Chem. 2007, 55, 6527-6532. [CrossRef] [PubMed]

50. Valero, D.; Valverde, J.M.; Martínez-Romero, D.; Guillén, F.; Castillo, S.; Serrano, M. The combination of modified atmosphere packaging with eugenol or thymol to maintain quality, safety and functional properties of table grapes. Postharvest Biol. Technol. 2006, 41, 317-327. [CrossRef]

(C) 2018 by the authors. Licensee MDPI, Basel, Switzerland. This article is an open access article distributed under the terms and conditions of the Creative Commons Attribution (CC BY) license (http://creativecommons.org/licenses/by/4.0/). 